\title{
Ural-European Parallels in the Eneolithic and the Bronze Age: Identification of Migrations (Methodological Approach)
}

\author{
S. A. Grigoriev \\ Institute of History and Archaeology, Ural Branch, Russian Academy of Sciences, Russia
}

Copyright $\mathrm{O} 2018$ by authors, all rights reserved. Authors agree that this article remains permanently open access under the terms of the Creative Commons Attribution License 4.0 International License

\begin{abstract}
The article is devoted to two episodes that allow us to speak about the presence of long-distance connections and contacts (or migrations) between the Urals and Europe during the Eneolithic and Bronze Age. The earlier Eneolithic contacts are represented by the Ural megaliths, which have parallels in Northwestern Europe. Later contacts are reflected in Bronze artifacts of the Seima-Turbino type and in tin alloys penetrating to Central and Western Europe from the east in the Late Bronze Age.
\end{abstract}

Keywords Eneolithic, Bronze Age, Megaliths, Metal Artifacts, Tin Alloys, the Urals, Northwestern Europe, Contacts

\section{Introduction}

There are two different approaches to archaeology. The first presumes that migration and external influences played a large role in the development of any area. The second approach presumes autochthonous local developments. Very often, we see various combinations of both of these approaches. Certainly, the absolutization of either of them is not often found in scientific literature. However, this problem is relevant to a variety of research fields in archaeology, including megalithic studies, the Indo-European problem, and many others.

Several years ago, I demonstrated that many archaeological cultures in Northern Eurasia had originated from the Middle East. Sintashta culture of the Southern Urals (early $2^{\text {nd }}$ millennium BC) is especially important, because though it includes a series of Eastern European components, most its features, especially architecture and metallurgy, had roots in the Middle East. In this case we have a detailed similarity; moreover, the similarity is complex, which allows talking about direct migration of people $[1,2]$. A model of migration was suggested that corresponded to the linguistic model of $\mathrm{T}$. Gamkrelidze and V. Ivanov [3]. Migrations of some peoples were shown on the basis of works of other colleagues; some connections were only outlined on the base of isolated features of material culture. But nowhere was there such a complex similarity, as in the case of Sintashta. This may reflect a lower degree of study of the problem, but also a somewhat special nature of the processes.

The complexity of archaeological reconstruction of migrations is also that migrants had always penetrated some local environment, and local cultural features were preserved in a transformed form. Therefore, similarities with remote areas often will be explained by our colleagues as merely accidental, or as arising from borrowing, etc. There are several other theories, but each of them is plagued by contradictions [4].

Here we see an obvious contradiction. Very many archeologists, discussing similarity of cultures in different areas, are ready to recognize this similarity, but explain it with cultural influences and contacts. But I have poor vision of a similar way of distribution of language.

As a matter of fact, even if the linguistic aspect of the Indo-European problem is ignored, there is the problem of the obvious similarities of different cultures that are separated by long distances. I tried to demonstrate that these similarities were influenced by long-distance migration that penetrated the Eurasian continent. However, the similarities of some features of material culture, for example, ceramics, are not always convincing. Even palaeogenetic studies are not always helpful in the solution of this problem. Hungary is a typical example, because the Hungarian language undoubtedly has eastern roots, but the modern Hungarians also exhibit genetic similarities with other people living in Central Europe. By the way, on the territory of Hungary the features of material culture introduced from the ancestral homeland in the early middle Ages, practically, did not appear, they had been lost in Eastern Europe. Therefore, if we did not have written 
sources and did not know the obvious fact that this is an isolated language, and related languages are localized in Siberia, it would be very difficult to prove the migration of Hungarians. On the other hand, many features of material culture are really transmitted through cultural influences, trade relations, etc. Especially it is true for some advanced technical achievements. For this, direct contacts are also necessary, but these contacts could be multistage.

Therefore, the best way to remain in the position of an archaeologist and to try to demonstrate either the occurrence of migration or influences using archaeological materials is a study of those aspects of culture that could not have been borrowed in the absence of direct contact, i.e., primarily complicated technologies and complicated ideological systems. In some instances, they could have convergent origins. If we see systematic similarities, however, we must discuss migration.

\section{Eneolithic links between Europe and the Urals}

We all know quite well about the role played by the Middle East in the spread of agriculture and cattle-breeding; in other words, in the neolithization of Europe. Today it is so universally recognized fact that it does not even need citing.

A bright example of this can be traced back in the Eneolithic. In recent years, we discovered several megalithic objects from this period in the Urals. They date from the $4^{\text {th }}$ to the $3^{\text {rd }}$ millennium BC and include menhirs, menhir complexes, dolmens and the ritual complex located on Vera Island [5]. The Vera Island complex consists of a series of megalithic chambers, a complex of menhirs and single menhirs, cult places, monumental sculptures, a stone quarry and several settlements of the period. The megalithic chambers differ from those in Europe, but have some detailed constructive similarities. In the settlements, rich archaeological materials were found: ceramics, stone tools, and the remains of metallurgical production.

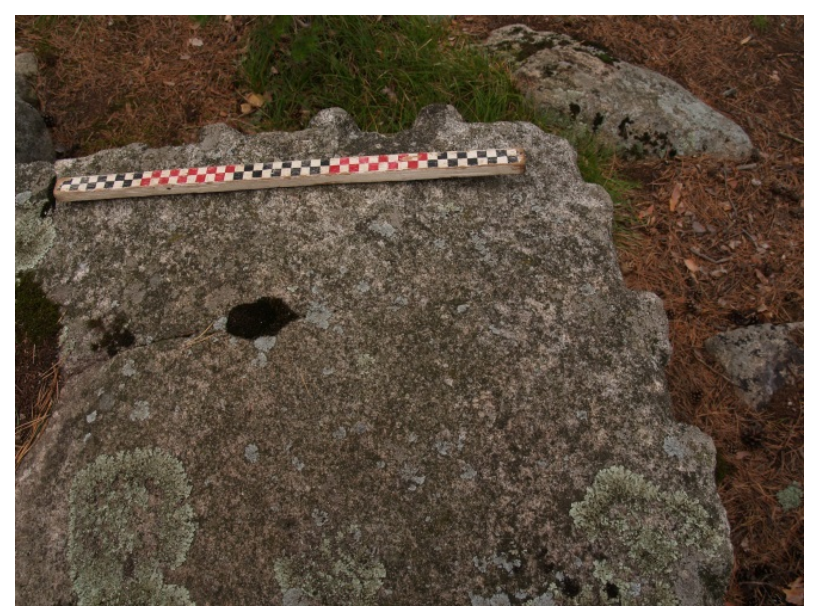

Figure 1. Quarry of the Vera Island. Trapezoid grooves for wooden wedges on the edges of stone blocks.
But we have here a series of significant problems in understanding the nature of these links.

These similarities can be divided into the common and specific ones. The first group consists of the following:

Technique of stone extraction of the quarry is the same as everywhere in megalithic Europe (Fig. 1). But the same technique was used in Egypt and ancient Peru. This similarity was caused by the single possibility to break stone - by means of wooden edges.

Our menhirs and stone rows have numerous parallels in the ancient world (Fig. 2). But each standing stone is similar to another.

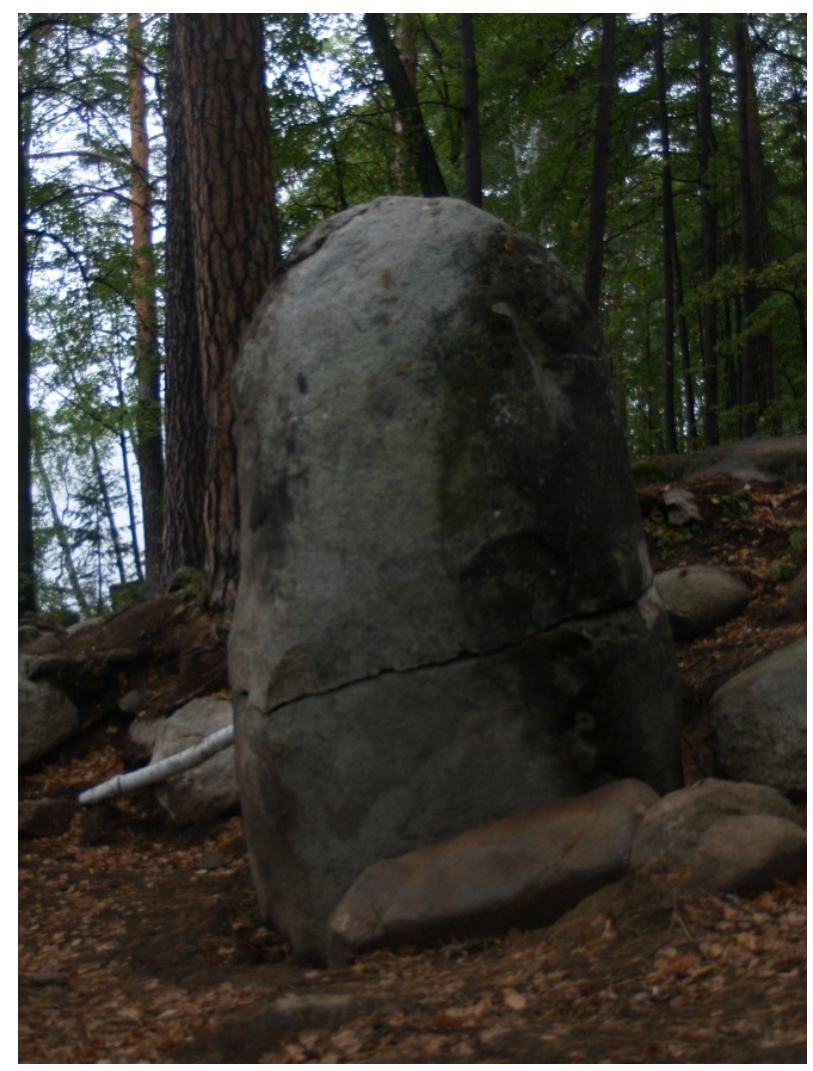

Figure 2. Grand menhir of the Vera Island.

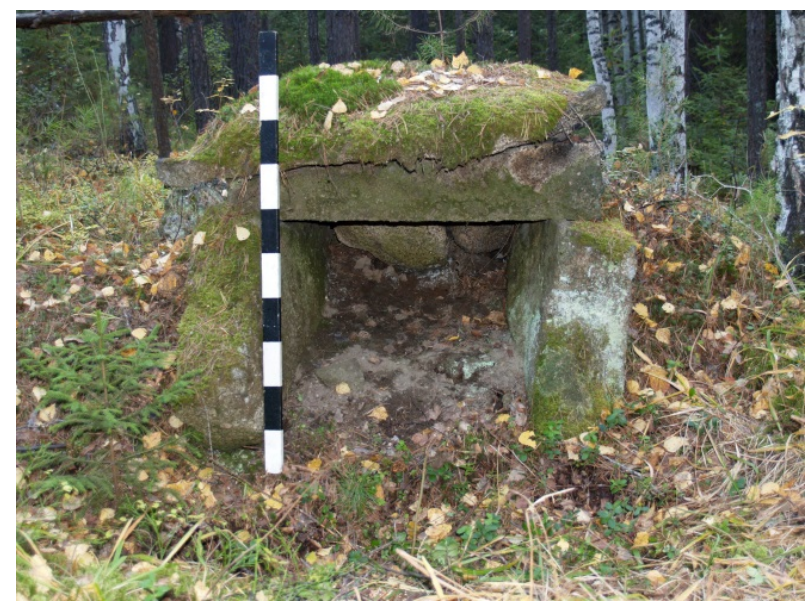

Figure 3. Dolmen in the Middle Urals. 
Even more complicated structures, like dolmens, are doubtful (Fig. 3). Of course, they have a lot of analogies in Europe and Levant, but if we take three stone slabs as the walls and the forth one to cover the constructions, they will be the same in any area, even without real connections.

Ural dolmens from large boulders have the same problem: their similarity is caused by the building material. Individual features of a stone platform found on the Vera Island (Fig. 4) have parallels from Portugal (menhir in a triangular fencing from vertically put small stone slabs) [6] to Scandinavia [7]. But we may admit the coincidence of this similarity too.

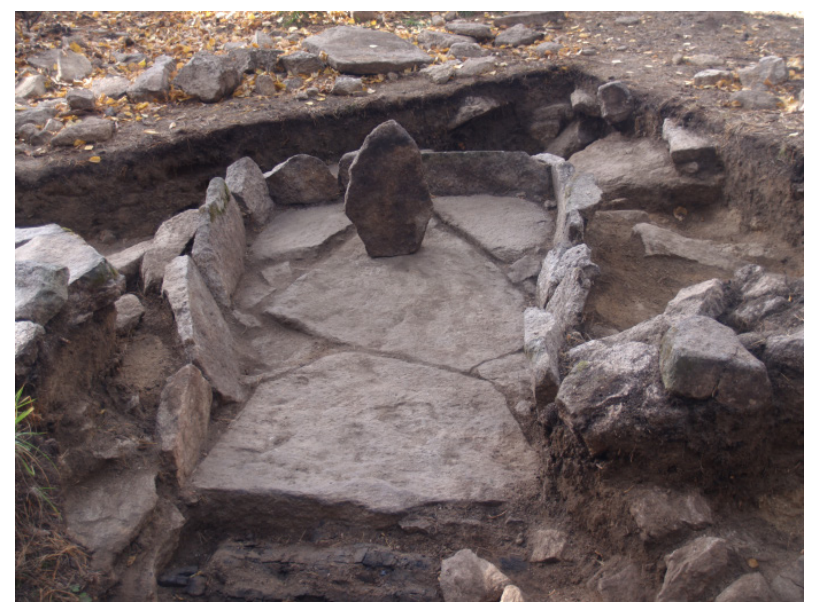

Figure 4. Stone platform on the settlement of Vera Island 4.

In large megalithic chambers we can find some detailed analogies, but usually they were caused by the building technique (Fig. 5).

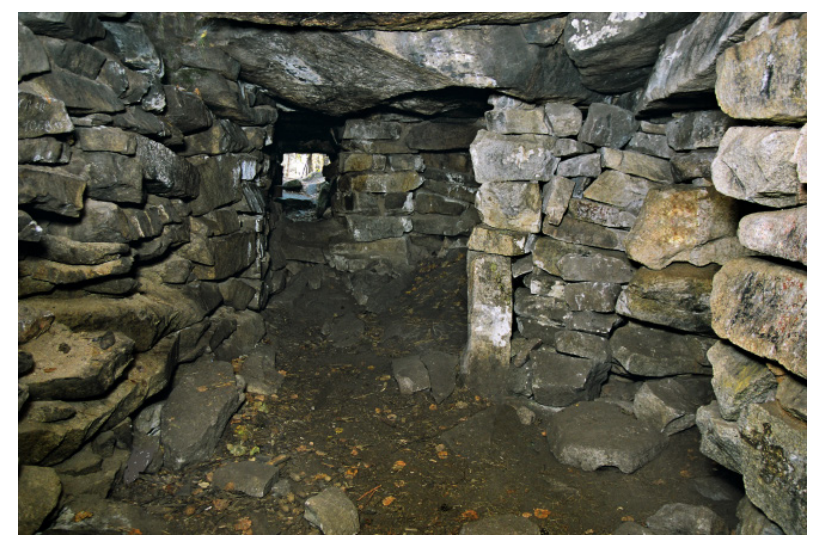

Figure 5. Interior of megalith 1 on the Vera Island.

Megalithic art in the Urals is presented by stone sculptures (Fig. 6). In Europe sculptural compositions are unknown. The megalithic art is presented there by engravings, rarer by painted images [8].

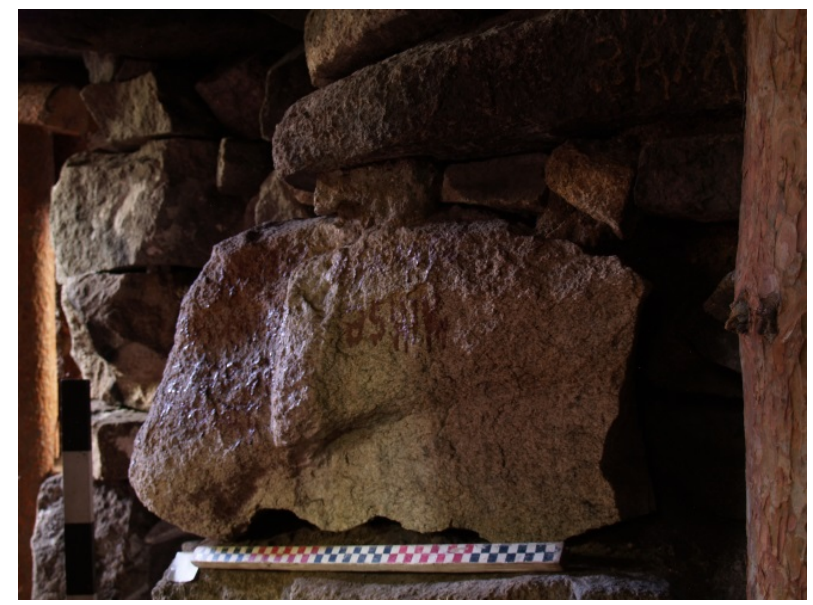

Figure 6. Sculptural bull's head in megalith 1 .

But some features are very similar, and it was caused not by the needs of building, but by a similar ideology.

Over the entrance to megalith 2 the lightbox is situated through which in the equinox beams of the setting sun get into the chamber illuminating a shelf and a niche (Fig. 7). A similar construction is revealed over the entrance to the passage grave of Newgrange, and there at sunrise around the winter solstice the sunlight gets into the chamber. Similar lightboxes are recorded also in other passage graves of Ireland and Scotland $[9,10]$.

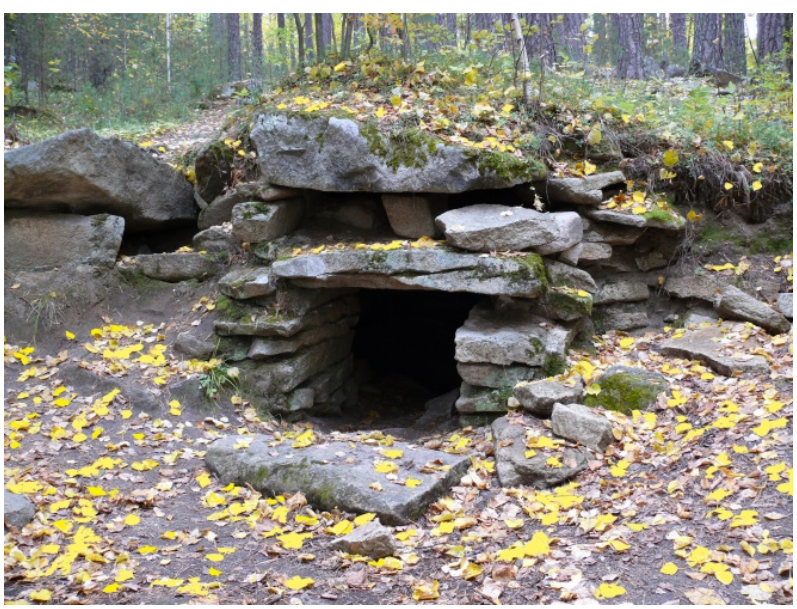

Figure 7. Megalith 2.

Another feature of this construction is also intriguing. At excavation in Newgrange two quartzite cubes have been found on the floor [11]. They served for sealing this lightbox. Similar stones lay in the lightbox of megalith 2 .

At last, in front of the entrance to our megalith a stone slab lies intended for closing of the entrance. However it could close it less than two-thirds of its height. In the Irish portal dolmens the portal was usually closed by a slab, in some cases on the full height, but frequently to a half [12]. 
Ural sanctuaries like Bakshai, Savin and Slobodchiki [13, 14], have analogies in rondels of Central Europe, but the circle was a universal symbol and could be reproduced independently, and the rondels have earlier chronological position. The combination on Bakshai of a ditch and a bank also belongs to the same line of parallels. But the location of the bank not inside (as usual), but outside of the ditch is present in England on such monuments as henges and the previous causewayed enclosures [15].

Certain parallel to the British stone rings is a ring of Akhunovo from eight upright stones with two central stones [16]. The holes inside the ring are interesting. Their analog is found at Stonehenge, so called Aubrey holes. But in general stone rings are universal structures that cannot be used as exact parallels.

Some European associations are caused also by the menhir complex of Vera Island because the lines between menhirs are directed to sunrise at different seasons. But even this is quite typical for many sanctuaries of antiquity, not at all connected with the European megalithic tradition.

European analogies in pottery (stab-and-drag, combed etc.) (Fig. 8) may be explained by long cultural contacts and influences, because similarities can be found from the Rhein to Eastern Europe and the Urals, a typical picture of cultural diffusion. But the situation with megaliths is more complicated, as well as in many areas of Europe.

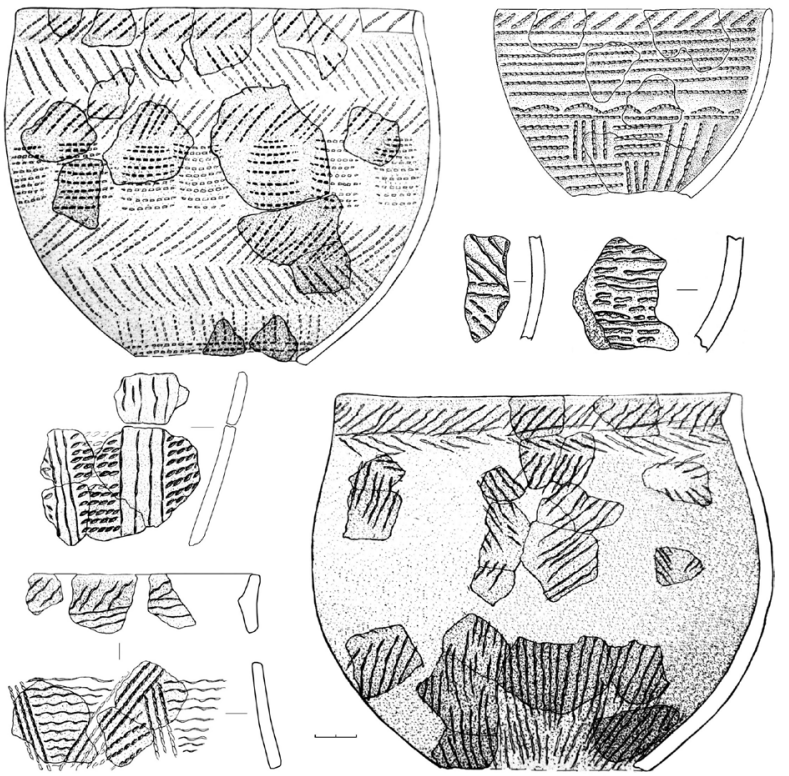

Figure 8. Pottery from the settlement of Vera Island 4 and complex of menhirs of Vera Island 9.

The conditions and reasons for the formation of megalithic cultures in Europe at the end of the Stone Age are a continuing topic of discussion. This discussion is rooted in the universal question of cultural development, including the roles of divergence versus convergence and local versus alien components. There are two main points of view. The first assumes that megalithic building in Europe resulted from migration from the Eastern Mediterranean region. Originally, this theory was formulated rather exotically [17], but later, more constructive ideas appeared [18-20]. A second theory assumes the universality of the local development of the megalithic traditions and provides a common explanation for their similarities: the demographic stress of agricultural populations migrating to the west who were halted by the Atlantic barrier [21]. However, this theory is not viable for the Urals, because there was no agriculture and there were no barriers that would prevent further movement.

Analogies between the Ural megalithic culture and that in Northwestern Europe assume migration. Yet, in both areas, there had to have been social conditions for the preservation of their cultural traditions. Furthermore, the construction of megaliths required a large number of builders [22]. Therefore, some European researchers came to the conclusion that there must have been a certain social hierarchy and a priestly caste [23-26]. In studying the Ural materials, we came to the same conclusion [27]. Therefore, there is a problem regarding the formation of the early hierarchical societies. It could occur in two ways: either as a result of the existence of surplus products based on an agricultural economy or the arrival of a new population that may have led to a social hierarchy. In the Urals, the latter explanation is the most plausible because of the existence of different ceramic complexes having local and European analogies.

Nevertheless, as a whole, we do not have a complex of strict parallels, for example, a discovery in the Urals of a European passage grave with appropriate ceramic and lithic tools. Therefore, the nature of this interaction at this early stage is yet to be understood. But the transfer to such a long distance of some building traditions and associated ideology and social structure were impossible without direct contacts.

\section{Migrations and the Bronze Age metallurgy}

Possibilities of later migrations from the east to west are more visible. In early history, mining and metallurgy were among the activities that significantly influenced the progress of mankind. There is a basic problem in the history of metallurgy, however. Some scholars believe that, because it involves a complicated production process, it could have been developed only once and in a single location. According to another point of view, it originated independently in different areas [see about the discussion 28]. In specific studies, this opposition is not so dramatic, though discussions about whether the origins/developments of metallurgy were local or alien are quite common. Naturally, it is impossible to solve the problem by studying the materials of a single local metallurgical complex/settlement. It is necessary to do a comparative analysis within as vast an area as possible.

While studying ancient metallurgy, it is very important to analyze metal artefacts. However, to solve the problems 
of ore sources and smelting technologies, we must study slag and ore.

Such a project was realized for the last years. Slag samples from the Bronze Age (and to a lesser extent, those from the Early Iron Age) found in the area from the Don River to the Altai Mountains and from Uzbekistan have been studied (in total, 2331 slag and ore samples and 2628 analyses). Based on these analyses, a generalized schema of the metallurgical development that occurred in Northern Eurasia has been created [29]. This project demonstrated a close interrelationship between types of ore/gangue and smelting technologies, and further, between methods of alloying, technologies of casting and forging, and types of tools/weapons.

This link between the use of particular alloys and types of ore is explainable [30]. Social processes stimulating expansion of metal consumption were a cornerstone of these changes. It led to change of the ore base that resulted in emergence of appropriate technologies of ore smelting, technologies and types of alloying. The mass transition to arsenic copper or to use of copper-arsenic ore became possible with transition from smelting pieces of malachite to smelting oxidized ore with fragments of rock. This type of alloying was possible in case of low-temperature smelting. After the territorial expansion of metallurgical technologies and increase in amounts of production in the Late Bronze Age, the mass use of ores from refractory rocks and copper-iron sulfides begins. It resulted in increase of smelting temperature and made impossible the alloys with arsenic because arsenic vaporized. Therefore a necessity to look for another alloying component was created. And it was tin. But, as its deposits were rare, specific conditions for its wide circulation were necessary.

For the Ural cultures of the early second millennium BC this connection is clearly visible: the same percentage of low-melting ores and arsenic bronze, the presence of arsenic only in the slag from low-melting ores, and arsenic inclusions in this slag.

Then, in the Late Bronze Age ${ }^{1}$, almost everywhere we see a transition from arsenic to tin alloys. And it corresponds to the transition from low-melting ores to refractory and sulfidic ores. And these patterns are present in all regions of Northern Eurasia. In most areas the production of tin alloys was precipitated by the introduction of smelting of sulfides and ores from quartz rocks which resulted in higher temperatures and a longer duration. In these conditions, the production of copper-arsenic alloys was impossible.

This process radically changed Eurasia. Tin deposits were rare, and tin was transported through large distances. In the early $2^{\text {nd }}$ millennium BC over a 50 -year period about 80 tons of tin could have been transported to Mesopotamia from the east. Tin from the Altai reached

1 The Eurasian Late Bronze Age corresponds in general to the Middle Bronze Age in Europe, but its beginning can be partly synchronized with the Reinecke's stage Br A2, i.e. the late stage of the Early Bronze Age. the Don River, and from British Islands to the Eastern Mediterranean. A net of tin trade was formed (this is well demonstrated by Muhly [31]. This made possible the rise of large copper mining centers on Cyprus, in Central Kazakhstan and some other areas. And this metal created a denser trade net. But, for the existence of this network created by metal, other goods should be included in it. Of course it was not the single reason, but it resulted in the rise of the first world trade system and influenced processes of regionalization and differentiation, but also numerous contacts and interplays of relation of different kinds. And we must keep in mind that in some instances these similarities between cultures could be provoked by this complicated net of relations. On the other hand, some migration could stimulate the inclusion of new areas in this network.

But we see that systematic smelting of copper-iron sulfides appeared first in the east and then it was distributed to the west. Episodically it took place in Europe earlier, but since the first half of the $2^{\text {nd }}$ millennium $\mathrm{BC}$ it became systematic. Contemporary we see penetration of Seima-Turbino metallurgy from the Altai to Eastern Europe since 2000 BC [32], and then further to the west: initially South-eastern and Central Europe (bronzes of the Langquaid Horizon) and then in other parts of Europe (Fig. 9) [33].

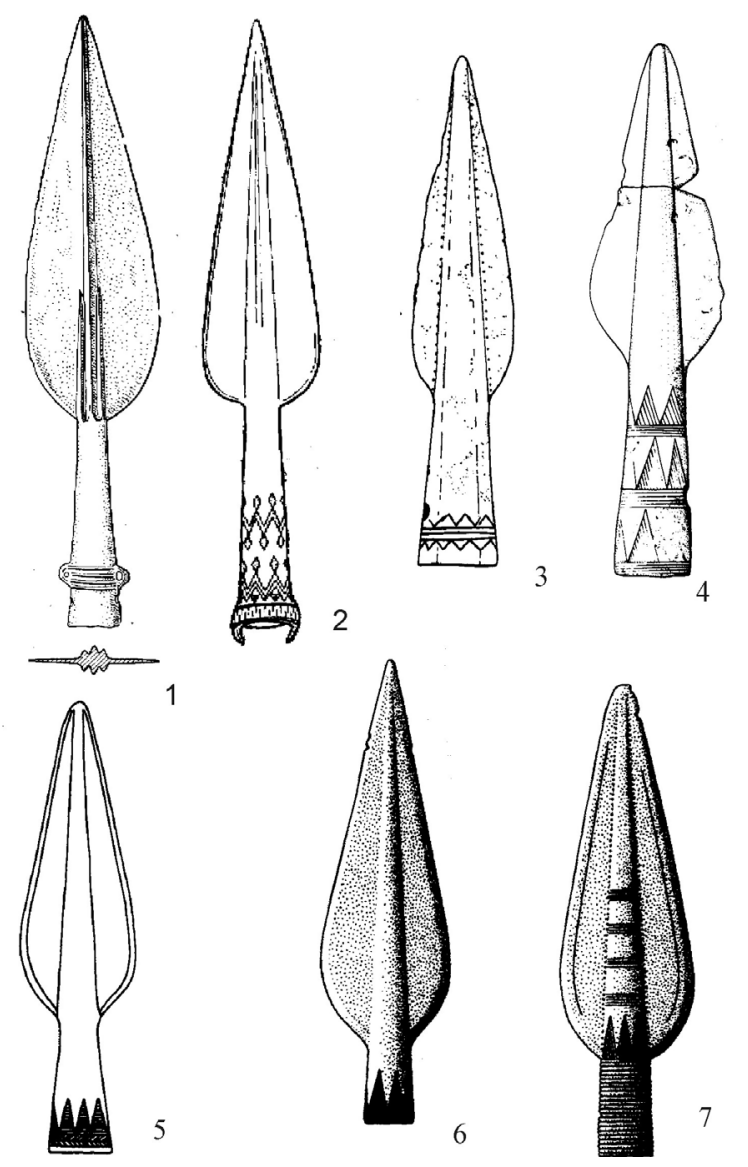

Figure 9. Bronze spearheads from Siberia $(1,2)$ and Central Europe (3-7): 1,2 - Rostovka; 3 - Langquaid; 4 - Nitriansky Hrádok; 4 Flonheim; 5-7 - Rederzhausen. 
The distribution of ore smelting technologies was impossible through areas where ore deposits were lacking (in this case Eastern Europe). Besides, all archaeometallurgists recognize that ancient metal production was based on chaînes opératoires ('chains of operations'), i.e. on interconnections of individual production cycles. Any type of raw material (types of ore and gangue) dictated definite smelting technologies. The latter were connected with types of alloying and through them with the metalworking technologies. The latter were the base of types of metal artifacts. So, it is a very complicated complex that cannot be gathered from several different isolated pieces. Therefore its sudden appearance is indicator of migration.

But, here we also have some problems. Perhaps in England, the use of bronze occurred earlier [34]. We see again the many-sided nature of these problems and their connection with social processes. The growth of metal consumption in the European Early Bronze Age led to the depletion of the former ore base (the use of ores without admixtures of rock, in particular, so-called fahlores). And we see the recognized links between the early phase of Wessex culture and the Únětice culture of Central Europe. Both are located in areas with tin sources. Thus, in this case, the processes of increasing consumption of metal common for the whole of Eurasia could stimulate the transition to new types of raw materials. And again we must make the choice: was this an immanent European process, or was it stimulated by external influences? But this question can be considered also not as this strict opposition. We must distinguish general processes of cultural and socio-economic development, local processes and external influences. And any ancient reality consisted of a complex combination of these components.

But the spread of eastern metal forms in Europe, together with changes in the ore base and types of alloys, was impossible without a direct coming of people. Another question is that the perception of these achievements in the European cultural space was prepared by the previous socio-economic development, the formed necessity, and the first independent steps in the same direction.

\section{Conclusions}

The identification of ancient migrations is a rather complex research task. Of course, the best option would be the existence of a complete set of similar artifacts, complemented by the genetic identity of the two paleopopulations. But these migrations were a much more complicated process than simply moving a group of people to a new area. They included groups of people on the road, assimilated local populations (or were themselves assimilated by local populations); they were forced to transform their culture in new conditions. Therefore, as it was said in the introduction, it is better to demonstrate it on the basis of those parts of culture, whose transmission is impossible without direct contacts, for example, a complex of technologies of metallurgy and metalworking or ideology embodied in a specific architecture. But we must remember that the words "better" and "only" are not synonymous. We can assume that some ancient migration can be reflected in some single artifact. All this depends on a specific situation and the general context.

All this needs further meticulous studies. But in general, we may conclude that the old-fashioned point of view about local developments everywhere does not work. In addition to the well-known process of Neolithization in Europe from the Near East and the following connection with the Eastern Mediterranean, there were many other contacts of European areas with eastern areas up to the Urals in the Copper and Bronze Age. In some instances we may speak about migrations in the others about influences and contact during the long time. But these were important processes determined many cultural features during the long period.

\section{REFERENCES}

[1] S. A. Grigoriev. Ancient Indo-Europeans, Rifei, Chelyabinsk, 2002.

[2] S. A. Grigoriev. Migratsii i ikh rol' v kulturogeneze Evrazii [Migrations and their role in cultural genesis in Eurasia] // Alyokshin, et al. (eds.). Kulturi stepnoï Evrazii I ikh vzaimodeïstvie $s$ drevnimi tsiviizatsiyami [Cultures of steppe Eurasia and their interplay with ancient civilizations] 2, Periphery, Sankt-Petersburg, 2012, 40-49.

[3] T. V. Gamkrelidze, V. V. Ivanov. Indo-European and the Indo-Europeans, De Gruyter, Berlin, New York, 1995.

[4] J. P. Mallory. In Search of the Indo-Europeans. Language, Archaeology and Myth, Thames \& Hudson, London, 1989.

[5] S. A. Grigoriev, J. V. Vasina. Megaliths of the Vera Island in the Southern Urals // D. Calado, M. Baldia, M. Boulanger (eds.). Monumental questions: prehistoric megaliths, mounds and enclosures, British archaeological report, Oxford, 2010, 179-185.

[6] V. Leisner. Die Megalithgräber der Iberischen Halbinsel. Der Westen, de Gruyter, Berlin, 1965, Taf. 13.

[7] J. Skaarup. Stengade. Ein langeländischer Wohnplatz mit Hausresten aus der Frühneolithischen Zeit, Langelands Museum, Rudkøbing, 161, 1975.

[8] E. S. Twohig. The megalithic art of Western Europe, Clarendon press, Oxford, 1981.

[9] F. Lynch. The use of the passage in certain passage graves as a means of communication rather than access // Daniel G., Kjærum P. (eds.) Megalithic graves and ritual, Jutland archaeological society, Moesgard, 1973, 147-162.

[10] J. V. S. Megaw, D. D. A. Simpson. Introduction to British prehistory, University press, Leicester, 1979. 
[11] G. Burenhult. New Grange: Temple of the sun // Burenhult G. (ed.). People of the Stone Age, Weldon Owen Pty, New York, 1993, 96, 97.

[12] R. De Valera, S. O'Nuallain. Survey of the megalithic tombs of Ireland. VI. County Clare, Stationary office, Dublin, 1961.

[13] V. K. Fedorov, Ya. V. Rafikova. Issledovaniya Novo-Bairamgulovskogo poseleniya (svyatilischa Bakshai) v 2010 godu [Studies of Novo-Bayramgulovo settlement (Bakshay sanctuary) in 2010], Bulletin VEGU, 6 (50), Ufa, 2010, 157-160.

[14] T. M. Potemkina. Svyatilischa eneolita I bronzovogo veka Zapadnoi Sibiri, kak istochnik astronomicheskih znanii I kosmologicheskih predstavlenii v drevnosti [Sanctuaries of the Eneolithic and Bronze Age of Western Siberia, as a source of astronomical knowledge and cosmological concepts in antiquity], Archaeoastronomy and Ancient Technologies, 2(1), 2014, 50-89.

[15] A. F. Harding, G. E. Lee. Henge monuments and related sites in Great Britain. Air photographic evidence and catalogue, British archaeological report, Oxford, 1987.

[16] F. N. Petrov, A. K. Kirillov. Issledovaniya megaliticheskogo kompleksa Akhunovo v 2003 godu [Research of the megalithic complex Ahunovo in 2003], Ufa archaeological bulletin, 6-7, 2007, 19-23.

[17] V. G. Childe. Prehistoric communities of the British Isles, Chambers, London, 1940.

[18] G. Daniel. The prehistoric chamber tombs of England and Wales, Cambridge University Press, Cambridge, 1950.

[19] G. Daniel. The prehistoric chamber tombs of France. A geographical, morphological and chronological survey, Thames and Hudson, London, 1960.

[20] S. O'Riordan, G. Daniel. New Grange and the Bend of the Boyne, Thames \& Hudson, London, 1964.

[21] C. Renfrew. Megaliths, territories and populations // De Laet J. (ed.). Acculturation and continuity in Atlantic Europe. Mainly during the Neolithic period and the Bronze Age, De Tempel, Brugge, 1976, 198-220.
[22] R. Bradley: Studying monuments // R. Bradley, J. Gardiner (eds.). Neolithic studies. A review of some current research, British archaeological reports 133, 1984, 61-66.

[23] J. D. Evans. The prehistoric antiquities of the Maltese islands: a survey, The Athlone Press, London, 1971.

[24] R. Joussaume. Dolmens for the Dead. Megalith-Building throughout the World, guild publishing, London, 1988.

[25] L. Kaelas: Megalithic monuments of Europe // De Laet S.J. (ed.). History of humanity. Vol. I. Prehistory and the beginnings of civilization, Taylor \& Francis, New York, 1994, 598-615.

[26] J. Maringer. The Gods of Prehistoric Man, Weidenfeld \& Nicolson, London, 1960.

[27] S. A. Grigoriev. Problemy sotsial'noï organizatsii v eneolite Urala [Problems of social organizations in the Ural Eneolithic] // M.K. Khabdullina (ed.). Margulanovskie chteniya - 2011, University press, Astana, 55-59, 2011.

[28] B. W. Roberts, C. P. Thornton, V. C. Pigott: Development of metallurgy in Eurasia. Antiquity, 83, 2009, 1012-1022.

[29] S. A. Grigoriev. Metallurgical Production in Northern Eurasia in the Bronze Age, Archaeopress, Oxford, 2015.

[30] S. A. Grigoriev. Social processes in Ancient Eurasia and development of types of alloys in metallurgical production, Archaeoastronomy and Ancient Technologies, V.5, No.2, 2017, 17-44.

[31] J. D. Muhly Copper and tin. The distribution of mineral resources and the nature of the metals trade in the Bronze Age, Archon Books, Hamden, 1973.

[32] E. N. Chernykh. Ancient metallurgy in the USSR: The Early Metal Age, Cambridge University Press, Cambridge, 1992.

[33] S. A. Grigoriev. Ancient Indo-Europeans, Rifei, Chelyabinsk, 2002.

[34] P. T. Craddock, B. R. Craddock. The beginnings of metallurgy in South-West Britain: hypotheses and evidence, Mining history: the Bulletin of the Peak district Mines Historical Society. Vol.13, No.2, 1996, 52. 